\title{
Best practice approaches to outpatient management of people living with Parkinson's disease during the COVID-19 pandemic
}

\author{
Antonia F. Demleitner ${ }^{1} \cdot$ Andreas W. Wolff $^{1}$ - Johanna Erber ${ }^{2} \cdot$ Friedemann Gebhardt $^{3}$ - Erica Westenberg ${ }^{1,4}$. \\ Andrea S. Winkler ${ }^{1,4,5} \cdot$ Susanne Kolbe-Busch ${ }^{6} \cdot$ Iris F. Chaberny $^{6} \cdot$ Paul Lingor $^{1,7,8}$ (i)
}

Received: 24 January 2022 / Accepted: 24 February 2022 / Published online: 4 March 2022

(c) The Author(s) 2022

\begin{abstract}
The prevalence of Parkinson's disease (PD) is rising, rendering it one of the most common neurodegenerative diseases. Treatment and monitoring of patients require regular specialized in- and outpatient care. Patients with PD are more likely to have a complicated disease course if they become infected with severe acute respiratory syndrome coronavirus type 2 (SARS-CoV-2). Regular in-hospital appointments place these patients at risk of exposure to SARS-CoV-2 due to travel and contact with other patients and staff. However, guidelines for the management of outpatients with PD during times of increased risk of infection are currently lacking. These are urgently needed to conduct risk-benefit evaluations to recommend the best medical treatment. This article discusses best practice approaches based on the current literature, as suggested by the multidisciplinary Network of University Medicine (NUM) in Germany. These include measures such as mask-wearing, hand hygiene, social distancing measures, and appropriate testing strategies in outpatient settings, which can minimize the risk of exposure. Furthermore, the urgency of appointments should be considered. Visits of low urgency may be conducted by general practitioners or via telemedicine consultations, whereas in-person presentation is required in case of moderate and high urgency visits. Classification of urgency should be carried out by skilled medical staff, and telemedicine (telephone or video consultations) may be a useful tool in this situation. The currently approved vaccines against SARS-CoV-2 are safe and effective for patients with PD and play a key role in minimizing infection risk for patients with PD.
\end{abstract}

Keywords COVID-19 $\cdot$ Parkinson's disease $\cdot$ Outpatients $\cdot$ Management $\cdot$ Best practice

Paul Lingor

Paul.Lingor@tum.de

1 Department of Neurology, School of Medicine, University Hospital München rechts der Isar, Technical University of Munich, Munich, Germany

2 Department of Internal Medicine II, School of Medicine, University Hospital München rechts der Isar, Technical University of Munich, Munich, Germany

3 Department of Hospital Hygiene, School of Medicine, University Hospital München rechts der Isar, Technical University of Munich, Munich, Germany

4 Center for Global Health, School of Medicine, University Hospital München rechts der Isar, Technical University of Munich, Munich, Germany
5 Centre for Global Health, Institute of Health and Society, School of Medicine, University of Oslo, Oslo, Norway

6 Institute of Hygiene, Hospital Epidemiology and Environmental Medicine, Leipzig University Hospital, Leipzig, Germany

7 DZNE, German Center for Neurodegenerative Diseases, Munich, Germany

8 Munich Cluster for Systems Neurology (SyNergy), Munich, Germany 


\section{Introduction}

Due to an aging population and ever-improving treatment options, the number of patients with Parkinson's disease (PD) is steadily increasing (Dorsey et al. 2018). This makes PD one of the fastest growing neurodegenerative diseases worldwide (Deuschl et al. 2020) which also requires substantial resources for specialized in- and outpatient care. Due to the chronic nature of the disease, PD patients require regular outpatient consultations to monitor disease progression, to assess social indicators of coping, and to adjust therapy (Richter et al. 2019). PD patients are also more likely to be hospitalized than peers of their age, e.g., due to a sudden worsening of symptoms as a result of an infection (Huse et al. 2005). The coronavirus disease 2019 (COVID-19) pandemic caused by the severe acute respiratory syndrome coronavirus type 2 (SARSCoV-2) continues to challenge healthcare systems worldwide. In many ways, it presents a more significant threat to patients with PD, especially as emerging variants of concern (VOC) further increase the contagiousness of the virus (Davies et al. 2021). If these patients are infected, the current treatment options for COVID-19, including IL6-blockers, neutralizing antibodies, and systemic corticosteroids, are still insufficient for preventing a severe course of disease (Rodriguez-Guerra et al. 2021), even if recent data on the ribonucleoside analog molnupiravir are promising (Mahase 2021). Therefore, best practice approaches for the management of outpatients with PD are urgently needed to control the infection risk for this vulnerable patient group. As part of Germany's national pandemic response, the Network of University Medicine (NUM) has developed best practice approaches for the management of outpatients in a pandemic situation that take into consideration the vulnerabilities and special medical needs of this patient population. This article will present a summary of the key issues that should be considered in the management of PD patients in the context of the current and potential future pandemics.

\section{Patients with PD are at an increased risk for a complicated COVID-19 disease course}

Older age and male sex are important risk factors for a severe course of and/or fatality after COVID-19 infection, as are diabetes, obesity, chronic obstructive pulmonary disease, dementia, or previous neurological disease (Williamson et al. 2020; Covino et al. 2020; Grasselli et al. 2020; Zhou et al. 2020; Bonanad et al. 2020; Ko et al. 2021). Pulmonary disease, obesity, and hypertension have also been specifically identified as risk factors for a severe COVID-19 disease course in PD patients (Chambergo-Michilot et al. 2021; Fasano et al. 2020c; Huber et al. 2021). Although the risk of a complicated COVID-19 disease course is increased for people with older age and associated arterial hypertension, this risk is even higher in PD patients, especially with longer disease duration, than in non-PD patients (Fasano et al. 2020b, c; Orlando et al. 2021; Chambergo-Michilot et al. 2021). PD patients may also have a higher mortality risk from COVID-19 infection per se (Zhang et al. 2020b; Rutten et al. 2020; Grasselli et al. 2020; Parihar et al. 2021). This calls for critical evaluation and planning of outpatient visits to provide sufficient care for these patients during the pandemic without placing them at an unnecessary risk of infection.

\section{Risk of exposure is increased by in-person appointments}

Healthcare delivery, regardless of the setting, carries a risk of exposure to individuals who have an acute SARS-CoV-2 infection; the magnitude of the risk also depends on the true local incidence for SARS-CoV-2. The potential risks for exposure can be found not only in the healthcare setting itself, but also along the patient's journey to an in-person appointment. For example, when taking public transportation, there is prolonged contact with potentially infectious people in what are usually poorly ventilated areas, so the risk of exposure to SARS-CoV-2 would increase accordingly. Once a patient has arrived at the treatment facility, vaccinated personnel can still potentially transmit the virus even if all recommended preventative measures have been followed, due to the emergence of highly transmissible or immune escape variants (Harris et al. 2021; Bailly et al. 2021; Kuzmina et al. 2021). Additionally, the facilities themselves, namely hospitals and outpatient clinics, have a concentration of potentially infectious patients and caregivers, which is why the implementation of entry-screening guidelines is vitally important. By assessing incoming patients and caregivers for typical COVID-19 symptoms and recent high-risk contacts, the risk of unscreened infectious individuals entering vulnerable areas can be reduced, but never completely abolished (Wang et al. 2020). Implementation of rapid testing strategies that include outpatients should therefore also be considered.

Due to the risks of infection in medical facilities (Richterman et al. 2020; Arons et al. 2020; Rickman et al. 2021), solutions must be implemented to mitigate the risk of inperson appointments. These include, but are not limited to, reducing exposure times in both waiting areas and examination/treatment rooms, as well as strictly adhering to standard practices for infection control, which encompass hand hygiene, respiratory hygiene (cough and sneeze etiquette), the use of medical face masks, and a no-handshake policy. In addition, the frequency of appointments should be adjusted to avoid prolonged gatherings in waiting areas. In model 
calculations for a room with four patients, of whom one is infectious, regular active ventilation reduces the individual risk of an infection from 36 to $15 \%$. Additional measures, such as wearing a face mask, reduce the individual risk to as low as $0.8 \%$, depending on the quality of the mask. A meta-analysis, which included studies from previous coronavirus outbreaks as well as the current pandemic, suggested that FFP2 (Filtering Face Piece Class 2)/KN95 respirator masks might provide better protection compared to regular face masks (Chu et al. 2020). In rooms where active ventilation is not possible, facilities should consider the usage of high-volume high-efficiency particulate air (HEPA) filtering devices (Lelieveld et al. 2020).

Special attention should be paid to patients returning from high-incidence regions, those who have been in contact with infected people and those recovering from a COVID-19 infection, in case of prolonged viral shedding and asymptomatic infections. Rigorous screening and testing concepts should also be implemented for patients coming from nursing homes, as virus transmission from asymptomatic patients has previously been linked to outbreaks (Byambasuren et al. 2020; Borras-Bermejo et al. 2020; Giri et al. 2021). Whenever possible, the number of people present at in-person appointments should be kept to a minimum and additional nursing personnel should only accompany patients if absolutely necessary. To further mitigate exposure risk, the duration of the visit should also be kept as short as possible.

\section{Assessment of urgency of in-person appointments}

Particular attention must be given to the urgency of a visit when scheduling outpatient visits for PD patients during a pandemic situation (Table 1) (Simonet et al. 2019). For example, routine visits can be considered low urgency visits if the patient is clinically stable. Here, it might be appropriate to refer the patients to the primary care physician/general practitioner (GP), whom the patient will also likely consult for other reasons, for performing laboratory tests or issuing follow-up prescriptions (Kearon and Risdon 2020). A visit may be classified as moderately urgent if a patient is experiencing a worsening of symptoms that limit activities of daily life and therefore require therapeutic intervention, but do not require immediate action, such as worsening of fine motor skills, continued reduction in walking distance, dysphonia, increasing cognitive impairment, mild depressive symptoms, or sleep disturbances. Lastly, severe worsening of symptoms, e.g., akinetic crisis, acute delirium, or acute deterioration due to other medical conditions such as infection or exsiccosis, is considered highly urgent and requires immediate attention and, in many cases, hospitalization (Gerlach et al. 2011; Woodford and Walker 2005). Patients with advanced PD may also need urgent attention due to the malfunction of device-aided therapies such as deep brain stimulation (DBS) or pump therapies (Miocinovic et al. 2020; Fasano et al. 2020a). Here, a specialized team experienced in the treatment of advanced PD stages must be involved.

Frequently, an assessment of urgency can be performed prior to in-person visits by means of video or telephone consultations between the patient, caregiver and/or family member and the treating neurologist or trained medical personnel from the outpatient clinics, such as a trained Parkinson nurse, nurse practitioner, or physician assistant (Fasano et al. 2020a). In this way, the risk of infection can be reduced for this vulnerable patient group. Another desirable option, which is not yet widely established, would be to remotely adjust DBS electrode settings with simultaneous video monitoring of therapeutic effects (Cerroni et al. 2020). Initial studies show a high level of satisfaction with the settings adjusted in a video consultation among patients in a Chinese cohort (Zhang et al. 2020a). However, if there is any doubt about the urgency of a visit, an immediate in-person appointment should be planned.

In a pandemic situation that is not completely controlled, such as in the case of exponential growth or the appearance of novel virus variants with yet unknown properties, the frequency of outpatient appointments may need to be rapidly adjusted. It is therefore recommended that clinics set up an appointment system that can inform patients quickly and easily about the date and modality of their next outpatient
Table 1 Exemplary reasons for an outpatient clinic visit in patients with PD, stratified by urgency level

\begin{tabular}{|c|c|c|}
\hline Low urgency & Moderate urgency & High urgency \\
\hline Routine visits without clinical worsening & Worsening of fine motor skills & Akinetic crisis \\
\hline Renewal of prescriptions & Reduction in walking distance & Acute delirium \\
\hline Routine control of DBS or pump therapy & Progressive cognitive impairment & Exsiccosis, infection \\
\hline \multirow[t]{3}{*}{ Routine laboratory controls } & $\begin{array}{l}\text { Adaptation of DBS or pump } \\
\text { therapy parameters }\end{array}$ & $\begin{array}{l}\text { Device dysfunction of } \\
\text { DBS aggregate or pump } \\
\text { therapy }\end{array}$ \\
\hline & Mild depressive symptoms & Acute depression \\
\hline & Dysphonia & Falls, trauma \\
\hline
\end{tabular}


visit. Digital scheduling solutions can save time for outpatient clinic staff and give patients more flexibility in choosing and rebooking visits.

\section{Telemedicine approaches should be implemented whenever possible}

However, not all PD patients are comfortable with digital solutions for scheduling and may prefer the conventional methods for making appointments and contacting their clinicians. Virtual appointments have been shown to have no negative impact on patients' quality of life (Beck et al. 2017; Hatcher-Martin et al. 2020), and there are clear advantages in efficiency, feasibility, and convenience, with a lower risk of exposure for both patients and practitioners. Unfortunately, telemedicine appointments are frequently financially less attractive to hospitals and are not always covered by health insurance in many countries (Dorsey et al. 2020; Patterson 2020). However, PD patients are generally willing to test telemedicine as an alternative to the traditional visits, and the usage of telemedicine approaches increased during the pandemic (Del Prete et al. 2020; Hassan et al. 2020). Currently, one of the most widely practiced approaches for remote physician-patient interaction is a telephone consultation, which has minimal technical requirements on both sides and can be implemented quickly. Several groups have described the success of using video rounds to provide a focused neurological examination, with some assistance from caregivers (Grossman et al. 2020; Fasano et al. 2020a). Smartphone applications (apps) increasingly enable patients to record symptoms themselves, although this greatly depends on the patient's capabilities and individual access to technical solutions (Miele et al. 2020). Particularly in the older patient population, clear limitations remain due to digital illiteracy, which may lead to difficulties in setting up video appointments or recording data in an app. Caregivers will need to assist in enabling access to these opportunities.

\section{Vaccinations against COVID-19 are safe and should be considered for all PD patients}

Apart from the aforementioned measures of infection control, vaccinations represent one of the most important pillars of the prevention strategy. Several mRNA-, vector-, and inactivated-virus-based vaccines against SARS-CoV-2 have been approved by the WHO and have proven safe and efficacious for reducing the risk of infection and complicated course of COVID-19 disease (Polack et al. 2020; Baden et al. 2021; Voysey et al. 2021; Sadoff et al. 2021; Tanriover et al.

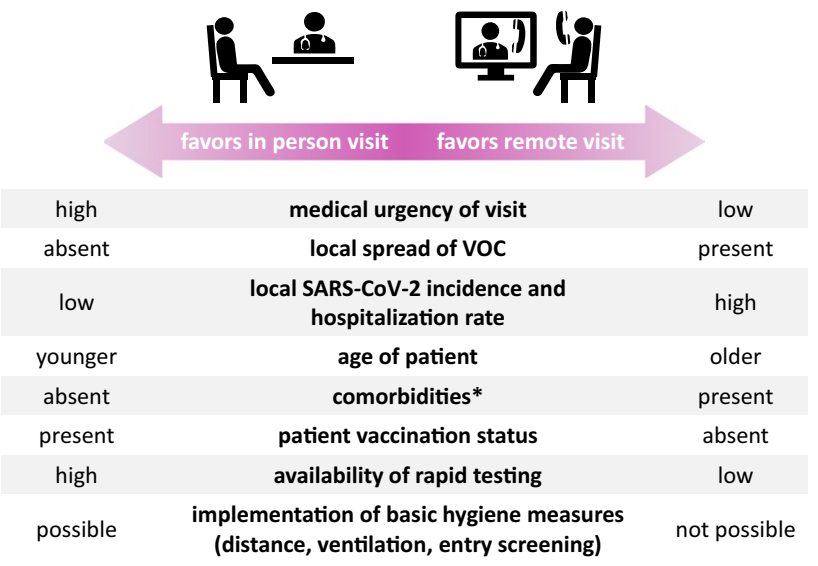

Fig. 1 Factors to consider when deciding whether an in-person visit or a telemedicine visit is preferred. VOC variant of concern. *Comorbidities predisposing to worse outcome in COVID-19, such as obesity, diabetes mellitus, chronic lung or kidney disease, cardiovascular disease, immune deficiency, or cancer

2021; Al Kaabi et al. 2021). Empirical evidence has also shown reduced transmission from breakthrough infections after vaccination (Shah et al. 2021). So far, there have been no data published that found any negative long-term consequences after administration to the at-risk population of $\mathrm{PD}$ patients (Bloem et al. 2021). Although the incidence is very rare, female patients and those under the age of 60 have a higher risk of cerebral venous thrombosis when vaccinated with vector-based vaccines, and therefore, mRNA-vaccines may be more appropriate in these groups (Greinacher et al. 2021). Nevertheless, there is currently no evidence that PD patients suffer more frequent or more dangerous side effects from currently approved vaccines. The Scientific Issue Committee of the International Parkinson and Movement Disorder Society therefore recommends that all patients with PD be vaccinated, especially those who are at increased risk for a lethal course of infection due to their advanced age or comorbidities (Bloem et al. 2021).

\section{Conclusion}

So far, best practice approaches on the management of outpatients with PD have been lacking. Therefore, an interdisciplinary team of the Netzwerk Universitätsmedizin (NUM) has developed recommendations based on the current literature as part of Germany's pandemic response. In summary, multiple factors should be considered when planning outpatient visits for patients with PD in the current pandemic situation. PD patients are at increased risk of complicated and fatal courses in the event of a SARS-CoV-2 infection. As outpatient clinic visits pose an increased risk of infection, the urgency of an in-person 
appointment for these patients should be carefully weighed against infection prevention. Other factors, such as the severity of the current local pandemic situation and the patient's individual risk profile, as well as their digital literacy, need to be considered as well (Fig. 1). A decision about whether a visit should be conducted in person or can be performed via telemedicine should only be made upon careful consideration of these factors. The implementation of such best practice approaches will facilitate the management of PD outpatients during the current COVID-19 pandemic and contribute to better preparedness for future pandemic situations.

Author contributions AFD, AWW, JE, FG, EW, ASW, SKB, IFC, and PL were part of the NUM B-FAST working group on outpatient management during the COVID-19 pandemic. AFD and PL prepared the manuscript draft. All authors revised and commented on the manuscript and approved the final manuscript version.

Funding Open Access funding enabled and organized by Projekt DEAL. This study was funded by the Network of German University Medicine (NUM), NaFoUniMedCovid19 (FKZ: 01KX2021), subproject B-FAST.

\section{Declarations}

Conflict of interest The authors declare that the research was conducted in the absence of any commercial or financial relationships that could be construed as a potential conflict of interest.

Ethics approval This article presents best practice approaches based on literature review. As no new data were generated in the process, no ethics approval was required.

Open Access This article is licensed under a Creative Commons Attribution 4.0 International License, which permits use, sharing, adaptation, distribution and reproduction in any medium or format, as long as you give appropriate credit to the original author(s) and the source, provide a link to the Creative Commons licence, and indicate if changes were made. The images or other third party material in this article are included in the article's Creative Commons licence, unless indicated otherwise in a credit line to the material. If material is not included in the article's Creative Commons licence and your intended use is not permitted by statutory regulation or exceeds the permitted use, you will need to obtain permission directly from the copyright holder. To view a copy of this licence, visit http://creativecommons.org/licenses/by/4.0/.

\section{References}

Al Kaabi N, Zhang Y, Xia S, Yang Y, Al Qahtani MM, Abdulrazzaq N, Al Nusair M, Hassany M, Jawad JS, Abdalla J, Hussein SE, Al Mazrouei SK, Al Karam M, Li X, Yang X, Wang W, Lai B, Chen W, Huang S, Wang Q, Yang T, Liu Y, Ma R, Hussain ZM, Khan T, Saifuddin Fasihuddin M, You W, Xie Z, Zhao Y, Jiang Z, Zhao G, Zhang Y, Mahmoud S, Eltantawy I, Xiao P, Koshy A, Zaher WA, Wang H, Duan K, Pan A, Yang X (2021) Effect of 2 inactivated SARS-CoV-2 vaccines on symptomatic COVID-19 infection in adults. JAMA 326(1):35-45. https://doi.org/10.1001/ jama.2021.8565

Arons MM, Hatfield KM, Reddy SC, Kimball A, James A, Jacobs JR, Taylor J, Spicer K, Bardossy AC, Oakley LP, Tanwar S, Dyal JW, Harney J, Chisty Z, Bell JM, Methner M, Paul P, Carlson CM, Mclaughlin HP, Thornburg N, Tong S, Tamin A, Tao Y, Uehara A, Harcourt J, Clark S, Brostrom-Smith C, Page LC, Kay M, Lewis J, Montgomery P, Stone ND, Clark TA, Honein MA, Duchin JS, Jernigan JA (2020) Presymptomatic SARS-CoV-2 infections and transmission in a skilled nursing facility. $\mathrm{N}$ Engl $\mathrm{J}$ Med 382(22):2081-2090. https://doi.org/10.1056/nejmoa2008457

Baden LR, El Sahly HM, Essink B, Kotloff K, Frey S, Novak R, Diemert D, Spector SA, Rouphael N, Creech CB, Mcgettigan J, Khetan S, Segall N, Solis J, Brosz A, Fierro C, Schwartz H, Neuzil K, Corey L, Gilbert P, Janes H, Follmann D, Marovich M, Mascola J, Polakowski L, Ledgerwood J, Graham BS, Bennett H, Pajon R, Knightly C, Leav B, Deng W, Zhou H, Han S, Ivarsson M, Miller J, Zaks T (2021) Efficacy and safety of the mRNA-1273 SARS-CoV-2 vaccine. N Engl J Med 384(5):403-416. https://doi. org/10.1056/nejmoa2035389

Bailly B, Guilpain L, Bouiller K, Chirouze C, N'Debi M, Soulier A, Demontant V, Pawlotsky J-M, Rodriguez C, Fourati S (2021) BNT162b2 mRNA vaccination did not prevent an outbreak of SARS COV-2 variant 501Y.V2 in an elderly nursing home but reduced transmission and disease severity. Clin Infect Dis. https:// doi.org/10.1093/cid/ciab446

Beck CA, Beran DB, Biglan KM, Boyd CM, Dorsey ER, Schmidt PN, Simone R, Willis AW, Galifianakis NB, Katz M, Tanner CM, Dodenhoff K, Aldred J, Carter J, Fraser A, Jimenez-Shahed J, Hunter C, Spindler M, Reichwein S, Mari Z, Dunlop B, Morgan JC, Mclane D, Hickey P, Gauger L, Richard IH, Mejia NI, Bwala G, Nance M, Shih LC, Singer C, Vargas-Parra S, Zadikoff C, Okon N, Feigin A, Ayan J, Vaughan C, Pahwa R, Dhall R, Hassan A, Demello S, Riggare SS, Wicks P, Achey MA, Elson MJ, Goldenthal S, Keenan HT, Korn R, Schwarz H, Sharma S, Stevenson EA, Zhu W (2017) National randomized controlled trial of virtual house calls for Parkinson disease. Neurology 89(11):1152-1161. https://doi.org/10.1212/wnl.0000000000004357

Bloem BR, Trenkwalder C, Sanchez-Ferro A, Kalia LV, Alcalay R, Chiang H-L, Kang UJ, Goetz C, Brundin P, Papa SM (2021) COVID-19 vaccination for persons with Parkinson's disease: light at the end of the tunnel? J Parkinsons Dis 11(1):3-8. https://doi.org/10.3233/jpd-212573

Bonanad C, García-Blas S, Tarazona-Santabalbina F, Sanchis J, Bertomeu-González V, Fácila L, Ariza A, Núñez J, Cordero A (2020) The effect of age on mortality in patients with COVID19: a meta-analysis with 611,583 subjects. J Am Med Dir Assoc 21(7):915-918. https://doi.org/10.1016/j.jamda.2020.05.045

Borras-Bermejo B, Martinez-Gomez X, San Miguel MG, Esperalba J, Anton A, Martin E, Selvi M, Abadias MJ, Roman A, Pumarola T, Campins M (2020) Asymptomatic SARS-CoV-2 infection in nursing homes, Barcelona, Spain. Emerg Infect Dis 26(9):2281-2283. https://doi.org/10.3201/eid2609.202603

Byambasuren O, Cardona M, Bell K, Clark J, McLaws M-L, Glasziou $\mathrm{P}$ (2020) Estimating the extent of asymptomatic COVID-19 and its potential for community transmission: systematic review and meta-analysis. Off $\mathbf{J}$ Assoc Med Microbiol Infect Dis Can 5(4):223-234. https://doi.org/10.3138/jammi-2020-0030

Cerroni R, Scalise S, Stefani A (2020) Coronavirus disease 2019 and management of advanced therapies in parkinson's disease; peculiar needs for deep brain stimulation patients? Mov Disord Clin Pract 7(7):875-876. https://doi.org/10.1002/mdc3.13033

Chambergo-Michilot D, Barros-Sevillano S, Rivera-Torrejón O, De La Cruz-Ku GA, Custodio N (2021) Factors associated with COVID-19 in people with Parkinson's disease: a systematic 
review and meta-analysis. Eur J Neurol 28(10):3467-3477. https://doi.org/10.1111/ene.14912

Chu DK, Akl EA, Duda S, Solo K, Yaacoub S, Schünemann HJ, Chu DK, Akl EA, El-Harakeh A, Bognanni A, Lotfi T, Loeb M, Hajizadeh A, Bak A, Izcovich A, Cuello-Garcia CA, Chen C, Harris DJ, Borowiack E, Chamseddine F, Schünemann F, Morgano GP, Muti Schünemann GEU, Chen G, Zhao H, Neumann I, Chan J, Khabsa J, Hneiny L, Harrison L, Smith M, Rizk N, Giorgi Rossi P, Abihanna P, El-Khoury R, Stalteri R, Baldeh T, Piggott T, Zhang Y, Saad Z, Khamis A, Reinap M, Duda S, Solo K, Yaacoub S, Schünemann HJ (2020) Physical distancing, face masks, and eye protection to prevent person-to-person transmission of SARS-CoV-2 and COVID-19: a systematic review and meta-analysis. The Lancet 395(10242):1973-1987. https://doi. org/10.1016/s0140-6736(20)31142-9

Covino M, De Matteis G, Santoro M, Sabia L, Simeoni B, Candelli M, Ojetti V, Franceschi F (2020) Clinical characteristics and prognostic factors in COVID-19 patients aged $\geq 80$ years. Geriatr Gerontol Int 20(7):704-708. https://doi.org/10.1111/ ggi. 13960

Davies NG, Abbott S, Barnard RC, Jarvis CI, Kucharski AJ, Munday JD, Pearson CAB, Russell TW, Tully DC, Washburne AD, Wenseleers T, Gimma A, Waites W, Wong KLM, Van Zandvoort K, Silverman JD, Diaz-Ordaz K, Keogh R, Eggo RM, Funk S, Jit M, Atkins KE, Edmunds WJ (2021) Estimated transmissibility and impact of SARS-CoV-2 lineage England. Science. https://doi.org/ 10.1126/science.abg3055

Del Prete E, Francesconi A, Palermo G, Mazzucchi S, Frosini D, Morganti R, Coleschi P, Raglione LM, Vanni P, Ramat S, Novelli A, Napolitano A, Battisti C, Giuntini M, Rossi C, Menichetti C, Ulivelli M, De Franco V, Rossi S, Bonuccelli U, Ceravolo R (2020) Prevalence and impact of COVID-19 in Parkinson's disease: evidence from a multi-center survey in Tuscany region. J Neurol 268(4):1179-1187. https://doi.org/10.1007/s00415-020-10002-6

Deuschl G, Beghi E, Fazekas F, Varga T, Christoforidi KA, Sipido E, Bassetti CL, Vos T, Feigin VL (2020) The burden of neurological diseases in Europe: an analysis for the global burden of disease study 2017. Lancet Public Health 5:e551-e567. https://doi.org/ 10.1016/s2468-2667(20)30190-0

Dorsey ER, Sherer T, Okun MS, Bloem BR (2018) The emerging evidence of the Parkinson pandemic. J Parkinsons Dis 8(s1):3-8. https://doi.org/10.3233/JPD-181474

Dorsey ER, Okun MS, Bloem BR (2020) Care, convenience, comfort, confidentiality, and contagion: the 5 C's that will shape the future of telemedicine. J Parkinsons Dis 10(3):893-897. https://doi.org/ 10.3233/jpd-202109

Fasano A, Antonini A, Katzenschlager R, Krack P, Odin P, Evans AH, Foltynie T, Volkmann J, Merello M (2020a) Management of advanced therapies in Parkinson's disease patients in times of humanitarian crisis: the COVID-19 experience. Mov Disord Clin Pract 7(4):361-372. https://doi.org/10.1002/mdc3.12965

Fasano A, Cereda E, Barichella M, Cassani E, Ferri V, Zecchinelli AL, Pezzoli G (2020b) COVID-19 in Parkinson's disease patients living in lombardy. Italy Mov Disord 35(7):1089-1093. https://doi. org/10.1002/mds. 28176

Fasano A, Elia AE, Dallocchio C, Canesi M, Alimonti D, Sorbera C, Alonso-Canovas A, Pezzoli G (2020c) Predictors of COVID19 outcome in Parkinson's disease. Parkinsonism Relat Disord 78:134-137. https://doi.org/10.1016/j.parkreldis.2020.08.012

Gerlach OHH, Winogrodzka A, Weber WEJ (2011) Clinical problems in the hospitalized Parkinson's disease patient: systematic review. Mov Disord 26(2):197-208. https://doi.org/10.1002/mds.23449

Giri S, Chenn LM, Romero-Ortuno R (2021) Nursing homes during the COVID-19 pandemic: a scoping review of challenges and responses. Eur Geriatr Med 16:1-10. https://doi.org/10.1007/ s41999-021-00531-2
Grasselli G, Greco M, Zanella A, Albano G, Antonelli M, Bellani G, Bonanomi E, Cabrini L, Carlesso E, Castelli G, Cattaneo S, Cereda D, Colombo S, Coluccello A, Crescini G, Forastieri Molinari A, Foti G, Fumagalli R, Iotti GA, Langer T, Latronico N, Lorini FL, Mojoli F, Natalini G, Pessina CM, Ranieri VM, Rech R, Scudeller L, Rosano A, Storti E, Thompson BT, Tirani M, Villani PG, Pesenti A, Cecconi M (2020) Risk factors associated with mortality among patients with covid-19 in intensive care units in Lombardy Italy. JAMA Internal Med 180(10):1345-1355. https:// doi.org/10.1001/jamainternmed.2020.3539

Greinacher A, Thiele T, Warkentin TE, Weisser K, Kyrle PA, Eichinger S (2021) Thrombotic thrombocytopenia after ChAdOx1 nCov-19 vaccination. N Engl J Med 384(22):2092-2101. https://doi.org/10. 1056/nejmoa2104840

Grossman SN, Han SC, Balcer LJ, Kurzweil A, Weinberg H, Galetta SL, Busis NA (2020) Rapid implementation of virtual neurology in response to the COVID-19 pandemic. Neurology 94(24):10771087. https://doi.org/10.1212/wnl.0000000000009677

Harris RJ, Hall JA, Zaidi A, Andrews NJ, Dunbar JK, Dabrera G (2021) Effect of vaccination on household transmission of SARS-CoV-2 in England. N Engl J Med 385:759-760. https://doi.org/10.1056/ nejmc 2107717

Hassan A, Mari Z, Gatto EM, Cardozo A, Youn J, Okubadejo N, Bajwa JA, Shalash A, Fujioka S, Aldaajani Z, Cubo E, Adams J, Afshari M, Aldaajani Z, Aldred J, Bajwa JA, Ben-Pazi H, Bloem B, Browne P, Buesing K, Cardozo A, Chan B, Chouinard S, Cubo E, Doumbe J, Dekker M, Fujioka S, Galifianakis N, Gatto E, Goetz C, Guttman M, Hassan A, Hatcher-Martin J, Katz M, Mari Z, Moukheiber E, Ojo O, Okubadejo N, Pantelyat A, Prakash N, Shalash A, Spindler M, Tanner C, Youn J (2020) Global survey on telemedicine utilization for movement disorder during the COVID-19 pandemic. Mov Disord 35(10):1701-1711. https:// doi.org/10.1002/mds.28284

Hatcher-Martin JM, Adams JL, Anderson ER, Bove R, Burrus TM, Chehrenama M, Dolan O'Brien M, Eliashiv DS, Erten-Lyons D, Giesser BS, Moo LR, Narayanaswami P, Rossi MA, Soni M, Tariq N, Tsao JW, Vargas BB, Vota SA, Wessels SR, Planalp H, Govindarajan R (2020) Telemedicine in neurology. Neurology 94(1):30-38. https://doi.org/10.1212/wnl.0000000000008708

Huber MK, Raichle C, Lingor P, Synofzik M, Borgmann S, Erber J, Tometten L, Rimili W, Dolff S, Wille K, Knauss S, Piepel C, Lanznaster J, Rieg S, Prasser F, Pilgram L, Spottke A, Klockgether T, Klein C, Hopfner F, Höglinger GU (2021) Outcomes of SARS$\mathrm{CoV}-2$ infections in patients with neurodegenerative diseases in the LEOSS Cohort. Mov Disord 36(4):791-793. https://doi.org/ $10.1002 / \mathrm{mds} .28554$

Huse DM, Schulman K, Orsini L, Castelli-Haley J, Kennedy S, Lenhart G (2005) Burden of illness in Parkinson's disease. Mov Disord 20(11):1449-1454. https://doi.org/10.1002/mds.20609

Kearon J, Risdon C (2020) The role of primary care in a pandemic: reflections during the COVID-19 pandemic in Canada. J Prim Care Commun Health 11:215013272096287. https://doi.org/10. $1177 / 2150132720962871$

Ko JY, Danielson ML, Town M, Derado G, Greenlund KJ, Kirley PD, Alden NB, Yousey-Hindes K, Anderson EJ, Ryan PA, Kim S, Lynfield R, Torres SM, Barney GR, Bennett NM, Sutton M, Talbot HK, Hill M, Hall AJ, Fry AM, Garg S, Kim L, Whitaker M, O’Halloran A, Holstein R, Garvin W, Chai SJ, Kawasaki B, Meek J, Openo KP, Monroe ML, Henderson J, Como-Sabetti K, Davis SS, Spina NL, Felsen CB, West N, Schaffner W, George A (2021) Risk factors for coronavirus disease 2019 (COVID-19)associated hospitalization: COVID-19-associated hospitalization surveillance network and behavioral risk factor surveillance system. Clin Infect Dis 72(11):e695-e703. https://doi.org/10.1093/ $\mathrm{cid} / \mathrm{ciaa} 1419$ 
Kuzmina A, Khalaila Y, Voloshin O, Keren-Naus A, Boehm-Cohen L, Raviv Y, Shemer-Avni Y, Rosenberg E, Taube R (2021) SARSCoV-2 spike variants exhibit differential infectivity and neutralization resistance to convalescent or post-vaccination sera. Cell Host Microbe 29(4):522-528.e522. https://doi.org/10.1016/j. chom.2021.03.008

Lelieveld J, Helleis F, Borrmann S, Cheng Y, Drewnick F, Haug G, Klimach T, Sciare J, Su H, Pöschl U (2020) Model calculations of aerosol transmission and infection risk of COVID-19 in indoor environments. Int J Environ Res Public Health 17(21):8114. https://doi.org/10.3390/ijerph17218114

Mahase E (2021) Covid-19: molnupiravir reduces risk of hospital admission or death by $50 \%$ in patients at risk. MSD Rep BMJ 375:n2422. https://doi.org/10.1136/bmj.n2422

Miele G, Straccia G, Moccia M, Leocani L, Tedeschi G, Bonavita S, Lavorgna L, Padovani A, Clerico M, Brigo F, Cocco E, Lanzillo R, Russo A, Giometto B, Trojsi F, Iodice R, Bucello S, Annovazzi P, Prosperini L, Stromillo ML, Repice AM, Abbadessa G, Lerario A, Demartino A, Bombaci A, Iodice F, Di Lorenzo F, Cuffaro L, Romoli M, Silvestro M, Alberto Artusi C (2020) Telemedicine in Parkinson's disease: how to ensure patient needs and continuity of care at the time of COVID-19 pandemic. Telemed e-Health 26(12):1533-1536. https://doi.org/10.1089/tmj.2020.0184

Miocinovic S, Ostrem JL, Okun MS, Bullinger KL, Riva-Posse P, Gross RE, Buetefisch CM (2020) Recommendations for deep brain stimulation device management during a pandemic. J Parkinsons Dis 10(3):903-910. https://doi.org/10.3233/JPD-202072

Orlando V, Rea F, Savaré L, Guarino I, Mucherino S, Perrella A, Trama U, Coscioni E, Menditto E, Corrao G (2021) Development and validation of a clinical risk score to predict the risk of SARSCoV-2 infection from administrative data: a population-based cohort study from Italy. PLoS ONE 16(1):e0237202. https://doi. org/10.1371/journal.pone.0237202

Parihar R, Ferastraoaru V, Galanopoulou AS, Geyer HL, Kaufman DM (2021) Outcome of hospitalized Parkinson's disease patients with and without COVID-19. Mov Disord Clin Pract 8(6):859-867. https://doi.org/10.1002/mdc3.13231

Patterson V (2020) Neurological telemedicine in the COVID-19 era. Nat Rev Neurol 17(2):73-74. https://doi.org/10.1038/ s41582-020-00438-9

Polack FP, Thomas SJ, Kitchin N, Absalon J, Gurtman A, Lockhart S, Perez JL, Pérez Marc G, Moreira ED, Zerbini C, Bailey R, Swanson KA, Roychoudhury S, Koury K, Li P, Kalina WV, Cooper D, Frenck RW, Hammitt LL, Türeci Ö, Nell H, Schaefer A, Ünal S, Tresnan DB, Mather S, Dormitzer PR, Şahin U, Jansen KU, Gruber WC (2020) Safety and efficacy of the BNT162b2 mRNA covid-19 vaccine. N Engl J Med 383(27):2603-2615. https://doi.org/10.1056/nejmoa2034577

Richter D, Bartig D, Muhlack S, Hartelt E, Scherbaum R, Katsanos A, Müller T, Jost W, Ebersbach G, Gold R, Krogias C, Tönges L (2019) Dynamics of Parkinson's disease multimodal complex treatment in Germany from 2010-2016: patient characteristics, access to treatment, and formation of regional centers. Cells 8(2):151. https://doi.org/10.3390/cells8020151

Richterman A, Meyerowitz EA, Cevik M (2020) Hospital-acquired SARS-CoV-2 infection. JAMA 324(21):2155-2156. https://doi. org/10.1001/jama.2020.21399

Rickman HM, Rampling T, Shaw K, Martinez-Garcia G, Hail L, Coen P, Shahmanesh M, Shin GY, Nastouli E, Houlihan CF (2021) Nosocomial transmission of coronavirus disease 2019: a retrospective study of 66 hospital-acquired cases in a London teaching hospital. Clin Infect Dis 72(4):690-693. https://doi. org/10.1093/cid/ciaa816

Rodriguez-Guerra M, Jadhav P, Vittorio TJ (2021) Current treatment in COVID-19 disease: a rapid review. Drugs in Context 10:1-8. https://doi.org/10.7573/dic.2020-10-3
Rutten JJS, van Loon AM, van Kooten J, van Buul LW, Joling KJ, Smalbrugge M, Hertogh C (2020) Clinical suspicion of COVID19 in nursing home residents: symptoms and mortality risk factors. J Am Med Dir Assoc 21(12):1791-1797. https://doi.org/ 10.1016/j.jamda.2020.10.034

Sadoff J, Gray G, Vandebosch A, Cárdenas V, Shukarev G, Grinsztejn B, Goepfert PA, Truyers C, Fennema H, Spiessens B, Offergeld K, Scheper G, Taylor KL, Robb ML, Treanor J, Barouch DH, Stoddard J, Ryser MF, Marovich MA, Neuzil KM, Corey L, Cauwenberghs N, Tanner T, Hardt K, Ruiz-Guiñazú J, Le Gars M, Schuitemaker H, Van Hoof J, Struyf F, Douoguih M (2021) Safety and efficacy of single-dose Ad26.COV2.S vaccine against Covid-19. N Engl J Med 384(23):2187-2201. https:// doi.org/10.1056/nejmoa2101544

Shah ASV, Gribben C, Bishop J, Hanlon P, Caldwell D, Wood R, Reid M, Mcmenamin J, Goldberg D, Stockton D, Hutchinson S, Robertson C, Mckeigue PM, Colhoun HM, Mcallister DA (2021) Effect of vaccination on transmission of SARS-CoV-2. N Engl J Med 385(18):1718-1720. https://doi.org/10.1056/nejmc 2106757

Simonet C, Tolosa E, Camara A, Valldeoriola F (2019) Emergencies and critical issues in Parkinson's disease. Pract Neurol 20(1):1525. https://doi.org/10.1136/practneurol-2018-002075

Tanriover MD, Doğanay HL, Akova M, Güner HR, Azap A, Akhan S, Köse Ş, Erdinç FŞ, Akalın EH, Tabak ÖF, Pullukçu H, Batum Ö, Şimşek Yavuz S, Turhan Ö, Yıldırmak MT, Köksal İ, Taşova Y, Korten V, Yılmaz G, Çelen MK, Altın S, Çelik İ, Bayındır Y, Karaoğlan İ, Yılmaz A, Özkul A, Gür H, Unal S, Kayaaslan B, Hasanoğlu İ, Dalkıran A, Aydos Ö, Çınar G, Akdemir-Kalkan İ, İnkaya AÇ, Aydin M, Çakir H, Yıldız J, Kocabıyık Ö, Arslan S, Nallı B, Demir Ö, Singil S, Ataman-Hatipoğlu Ç, TuncerErtem G, Kınıklı S, Önal U, Mete B, Dalgan G, Taşbakan M, Yamazhan T, Kömürcüoğlu B, Yalnız E, Benli A, Keskin-Sarıtaş Ç, Ertosun MG, Özkan Ö, Emre S, Arıca S, Kuşçu F, Candevir A, Ertürk-Şengel B, Ayvaz F, Aksoy F, Mermutluoğlu Ç, Demir Y, Günlüoğlu G, Tural-Önür S, Kilıç-Toker A, Eren E, Otlu B, Mete AÖ, Koçak K, Ateş H, Koca-Kalkan İ, Aksu K (2021) Efficacy and safety of an inactivated whole-virion SARS-CoV-2 vaccine (CoronaVac): interim results of a double-blind, randomised, placebo-controlled, phase 3 trial in Turkey. The Lancet 398(10296):213-222. https://doi.org/10.1016/s0140-6736(21) 01429-x

Voysey M, Clemens SAC, Madhi SA, Weckx LY, Folegatti PM, Aley PK, Angus B, Baillie VL, Barnabas SL, Bhorat QE, Bibi S, Briner C, Cicconi P, Collins AM, Colin-Jones R, Cutland CL, Darton TC, Dheda K, Duncan CJA, Emary KRW, Ewer KJ, Fairlie L, Faust SN, Feng S, Ferreira DM, Finn A, Goodman AL, Green CM, Green CA, Heath PT, Hill C, Hill H, Hirsch I, Hodgson SHC, Izu A, Jackson S, Jenkin D, Joe CCD, Kerridge S, Koen A, Kwatra G, Lazarus R, Lawrie AM, Lelliott A, Libri V, Lillie PJ, Mallory R, Mendes AVA, Milan EP, Minassian AM, Mcgregor A, Morrison H, Mujadidi YF, Nana A, O'Reilly PJ, Padayachee SD, Pittella A, Plested E, Pollock KM, Ramasamy MN, Rhead S, Schwarzbold AV, Singh N, Smith A, Song R, Snape MD, Sprinz E, Sutherland RK, Tarrant R, Thomson EC, Török ME, Toshner M, Turner DPJ, Vekemans J, Villafana TL, Watson MEE, Williams CJ, Douglas AD, Hill AVS, Lambe T, Gilbert SC, Pollard AJ, Aban M, Abayomi F, Abeyskera K, Aboagye J, Adam M, Adams K, Adamson J, Adelaja YA, Adewetan G, Adlou S, Ahmed K, Akhalwaya Y, Akhalwaya S, Alcock A, Ali A, Allen ER, Allen L, Almeida TCDSC, Alves MPS, Amorim F, Andritsou F, Anslow R, Appleby M, Arbe-Barnes EH, Ariaans MP, Arns B, Arruda L, Azi P, Azi L, Babbage G, Bailey C, Baker KF, Baker M, Baker N, Baker P, Baldwin L, Baleanu I, Bandeira D, Bara A, Barbosa MAS, Barker D, Barlow GD, Barnes E, Barr AS, Barrett JR, Barrett J, Bates L, Batten A, Beadon K, Beales E, Beckley R, 
Belij-Rammerstorfer S, Bell J, Bellamy D, Bellei N, Belton S, Berg A, Bermejo L, Berrie E, Berry L, Berzenyi D, Beveridge A, Bewley KR, Bexhell H, Bhikha S, Bhorat AE, Bhorat ZE, Bijker E, Birch G, Birch S, Bird A, Bird O, Bisnauthsing K, Bittaye M, Blackstone K, Blackwell L, Bletchly H, Blundell CL, Blundell SR, Bodalia P, Boettger BC, Bolam E, Boland E, Bormans D, Borthwick N, Bowring F, Boyd A, Bradley P, Brenner T, Brown P, Brown C, Brown-O'Sullivan C, Bruce S, Brunt E, Buchan R, Budd W, Bulbulia YA, Bull M, Burbage J, Burhan H, Burn A, Buttigieg KR, Byard N, Cabera Puig I, Calderon G, Calvert A, Camara S, Cao M, Cappuccini F, Cardoso JR, Carr M, Carroll MW, Carson-Stevens A, Carvalho YDM, Carvalho JAM, Casey HR, Cashen P, Castro T, Castro LC, Cathie K, Cavey A, CerbinoNeto J, Chadwick J, Chapman D, Charlton S, Chelysheva I, Chester O, Chita S, Cho J-S, Cifuentes L, Clark E, Clark M, Clarke A, Clutterbuck EA, Collins SLK, Conlon CP, Connarty S, Coombes N, Cooper C, Cooper R, Cornelissen L, Corrah T, Cosgrove C, Cox T, Crocker WEM, Crosbie S, Cullen L, Cullen D, Cunha DRMF, Cunningham C, Cuthbertson FC, Da Guarda SNF, Da Silva LP, Damratoski BE, Danos Z, Dantas MTDC, Darroch P, Datoo MS, Datta C, Davids M, Davies SL, Davies H, Davis E, Davis J, Davis J, De Nobrega MMD, De Oliveira Kalid LM, Dearlove D, Demissie T, Desai A, Di Marco S, Di Maso C, Dinelli MIS, Dinesh T, Docksey C, Dold C, Dong T, Donnellan FR, Dos Santos T, Dos Santos TG, Dos Santos EP, Douglas N, Downing C, Drake J, Drake-Brockman R, Driver K, Drury R, Dunachie SJ, Durham BS, Dutra L, Easom NJW, Van Eck S, Edwards M, Edwards NJ, El Muhanna OM, Elias SC, Elmore M, English M, Esmail A, Essack YM, Farmer E, Farooq M, Farrar M, Farrugia L, Faulkner B, Fedosyuk S, Felle S, Feng S, Ferreira Da Silva C, Field S, Fisher R, Flaxman A, Fletcher J, Fofie H, Fok H, Ford KJ, Fowler J, Fraiman PHA, Francis E, Franco MM, Frater J, Freire MSM, Fry SH, Fudge S, Furze J, Fuskova M, Galian-Rubio P, Galiza E, Garlant H, Gavrila M, Geddes A, Gibbons KA, Gilbride C, Gill H, Glynn S, Godwin K, Gokani K, Goldoni UC, Goncalves M, Gonzalez IGS, Goodwin J, Goondiwala A, Gordon-Quayle K, Gorini G, Grab J, Gracie L, Greenland M, Greenwood N, Greffrath J, Groenewald MM, Grossi L, Gupta G, Hackett M, Hallis B, Hamaluba M, Hamilton E, Hamlyn J, Hammersley D, Hanrath AT, Hanumunthadu B, Harris SA, Harris C, Harris T, Harrison TD, Harrison D, Hart TC, Hartnell B, Hassan S, Haughney J, Hawkins S, Hay J, Head I, Henry J, Hermosin Herrera M, Hettle DB, Hill J, Hodges G, Horne E, Hou MM, Houlihan C, Howe E, Howell N, Humphreys J, Humphries HE, Hurley K, Huson C, Hyder-Wright A, Hyams C, Ikram S, Ishwarbhai A, Ivan M, Iveson P, Iyer V, Jackson F, De Jager J, Jaumdally S, Jeffers H, Jesudason N, Jones B, Jones K, Jones E, Jones C, Jorge MR, Jose A, Joshi A, Júnior EAMS, Kadziola J, Kailath R, Kana F, Karampatsas K, Kasanyinga M, Keen J, Kelly EJ, Kelly DM, Kelly D, Kelly S, Kerr D, Kfouri RDÁ, Khan L, Khozoee B, Kidd S, Killen A, Kinch J, Kinch P, King LDW, King TB, Kingham L, Klenerman P, Knapper F, Knight JC, Knott D, Koleva S, Lang M, Lang G, Larkworthy CW, Larwood JPJ, Law R, Lazarus EM, Leach A, Lees EA, Lemm N-M, Lessa A, Leung S, Li Y, Lias AM, Liatsikos K, Linder A, Lipworth S, Liu S, Liu X, Lloyd A, Lloyd S, Loew L, Lopez Ramon R, Lora L, Lowthorpe V, Luz K, Macdonald JC, Macgregor G, Madhavan M, Mainwaring DO, Makambwa E, Makinson R, Malahleha M, Malamatsho R, Mallett G, Mansatta K, Maoko T, Mapetla K, Marchevsky NG, Marinou S, Marlow E, Marques GN, Marriott P, Marshall RP, Marshall JL, Martins FJ, Masenya M, Masilela M, Masters SK, Mathew M, Matlebjane H, Matshidiso K, Mazur O, Mazzella A, Mccaughan H, Mcewan J, Mcglashan J, Mcinroy L, Mcintyre Z, Mclenaghan D, Mcrobert N, Mcswiggan S, Megson C, Mehdipour S, Meijs W, Mendonça RNÁ, Mentzer AJ, Mirtorabi N, Mitton C, Mnyakeni S, Moghaddas F, Molapo K, Moloi M, Moore M, Moraes-Pinto MI, Moran
M, Morey E, Morgans R, Morris S, Morris S, Morris HC, Morselli F, Morshead G, Morter R, Mottal L, Moultrie A, Moya N, Mpelembue M, Msomi S, Mugodi Y, Mukhopadhyay E, Muller J, Munro A, Munro C, Murphy S, Mweu P, Myasaki CH, Naik G, Naker K, Nastouli E, Nazir A, Ndlovu B, Neffa F, Njenga C, Noal H, Noé A, Novaes G, Nugent FL, Nunes G, O’Brien K, O'Connor D, Odam M, Oelofse S, Oguti B, Olchawski V, Oldfield NJ, Oliveira MG, Oliveira C, Oosthuizen A, O'Reilly P, Osborne P, Owen DRJ, Owen L, Owens D, Owino N, Pacurar M, Paiva BVB, Palhares EMF, Palmer S, Parkinson S, Parracho HMRT, Parsons K, Patel D, Patel B, Patel F, Patel K, Patrick-Smith M, Payne RO, Peng Y, Penn EJ, Pennington A, Peralta Alvarez MP, Perring J, Perry N, Perumal R, Petkar S, Philip T, Phillips DJ, Phillips J, Phohu MK, Pickup L, Pieterse S, Piper J, Pipini D, Plank M, Du Plessis J, Pollard S, Pooley J, Pooran A, Poulton I, Powers C, Presa FB, Price DA, Price V, Primeira M, Proud PC, ProvstgaardMorys S, Pueschel S, Pulido D, Quaid S, Rabara R, Radford A, Radia K, Rajapaska D, Rajeswaran T, Ramos ASF, Ramos Lopez F, Rampling T, Rand J, Ratcliffe H, Rawlinson T, Rea D, Rees B, Reiné J, Resuello-Dauti M, Reyes Pabon E, Ribiero CM, Ricamara M, Richter A, Ritchie N, Ritchie AJ, Robbins AJ, Roberts H, Robinson RE, Robinson H, Rocchetti TT, Rocha BP, Roche S, Rollier C, Rose L, Ross Russell AL, Rossouw L, Royal S, Rudiansyah I, Ruiz S, Saich S, Sala C, Sale J, Salman AM, Salvador N, Salvador S, Sampaio M, Samson AD, Sanchez-Gonzalez A, Sanders H, Sanders K, Santos E, Santos-Guerra MFS, Satti I, Saunders JE, Saunders C, Sayed A, Schim Van Der Loeff I, Schmid AB, Schofield E, Screaton G, Seddiqi S, Segireddy RR, Senger R, Serrano S, Shah R, Shaik I, Sharpe HE, Sharrocks K, Shaw R, Shea A, Shepherd A, Shepherd JG, Shiham F, Sidhom E, Silk SE, Da Silva Moraes AC, Silva-Junior G, Silva-Reyes L, Silveira AD, Silveira MBV, Sinha J, Skelly DT, Smith DC, Smith N, Smith HE, Smith DJ, Smith CC, Soares A, Soares T, Solórzano C, Sorio GL, Sorley K, Sosa-Rodriguez T, Souza CL, Souza BF, Souza AR, Spencer AJ, Spina F, Spoors L, Stafford L, Stamford I, Starinskij I, Stein R, Steven J, Stockdale L, Stockwell LV, Strickland LH, Stuart AC, Sturdy A, Sutton N, Szigeti A, TahiriAlaoui A, Tanner R, Taoushanis C, Tarr AW, Taylor K, Taylor U, Taylor IJ, Taylor J, Te-Naude R, Themistocleous Y, Themistocleous A, Thomas M, Thomas K, Thomas TM, Thombrayil A, Thompson F, Thompson A, Thompson K, Thompson A, Thomson J, Thornton-Jones V, Tighe PJ, Tinoco LA, Tiongson G, Tladinyane B, Tomasicchio M, Tomic A, Tonks S, Towner J, Tran N, Tree J, Trillana G, Trinham C, Trivett R, Truby A, Tsheko BL, Turabi A, Turner R, Turner C, Ulaszewska M, Underwood BR, Varughese R, Verbart D, Verheul M, Vichos I, Vieira T, Waddington CS, Walker L, Wallis E, Wand M, Warbick D, Wardell T, Warimwe G, Warren SC, Watkins B, Watson E, Webb S, WebbBridges A, Webster A, Welch J, Wells J, West A, White C, White R, Williams P, Williams RL, Winslow R, Woodyer M, Worth AT, Wright D, Wroblewska M, Yao A, Zimmer R, Zizi D, Zuidewind $P$ (2021) Safety and efficacy of ChAdOx1 nCoV-19 vaccine (AZD1222) against SARS-CoV-2: an interim analysis of four randomised controlled trials in Brazil, South Africa, and the UK. The Lancet 397:99-111. https://doi.org/10.1016/s0140-6736(20) 32661-1

Wang Q, Wang X, Lin H (2020) The role of triage in the prevention and control of COVID-19. Infect Control Hosp Epidemiol 41(7):772776. https://doi.org/10.1017/ice.2020.185

Williamson EJ, Walker AJ, Bhaskaran K, Bacon S, Bates C, Morton CE, Curtis HJ, Mehrkar A, Evans D, Inglesby P, Cockburn J, Mcdonald HI, Mackenna B, Tomlinson L, Douglas IJ, Rentsch CT, Mathur R, Wong AYS, Grieve R, Harrison D, Forbes H, Schultze A, Croker R, Parry J, Hester F, Harper S, Perera R, Evans SJW, Smeeth L, Goldacre B (2020) Factors associated 
with COVID-19-related death using OpenSAFELY. Nature 584(7821):430-436. https://doi.org/10.1038/s41586-020-2521-4

Woodford H, Walker R (2005) Emergency hospital admissions in idiopathic Parkinson's disease. Mov Disord 20(9):1104-1108. https:// doi.org/10.1002/mds.20485

Zhang C, Zhu K, Lin Z, Huang P, Pan Y, Sun B, Li D (2020a) Utility of deep brain stimulation telemedicine for patients with movement disorders during the COVID-19 outbreak in China. Neuromodul Technol Neural Interface 24(2):337-342. https://doi.org/10.1111/ ner. 13274

Zhang Q, Schultz JL, Aldridge GM, Simmering JE, Narayanan NS (2020b) Coronavirus disease 2019 case fatality and Parkinson's disease. Mov Disord 35(11):1914-1915. https://doi.org/10.1002/ mds. 28325
Zhou F, Yu T, Du R, Fan G, Liu Y, Liu Z, Xiang J, Wang Y, Song B, Gu X, Guan L, Wei Y, Li H, Wu X, Xu J, Tu S, Zhang Y, Chen H, Cao B (2020) Clinical course and risk factors for mortality of adult inpatients with COVID-19 in Wuhan, China: a retrospective cohort study. The Lancet 395(10229):1054-1062. https://doi.org/ 10.1016/s0140-6736(20)30566-3

Publisher's Note Springer Nature remains neutral with regard to jurisdictional claims in published maps and institutional affiliations. 